\title{
Labyrinthe
}

31 | 2008 (3)

Revues modes d'emploi

\section{Le temps des revues}

\section{(2) OpenEdition}

1 Journals

Édition électronique

URL : http://journals.openedition.org/labyrinthe/3866

DOI : $10.4000 /$ labyrinthe.3866

ISSN : 1950-6031

Éditeur

Hermann

\section{Édition imprimée}

Date de publication : 15 octobre 2008

ISBN : 978-2-9526131-8-7

Référence électronique

"Le temps des revues », Labyrinthe [En ligne], 31 | 2008 (3), mis en ligne le 08 novembre 2008, consulté le 09 mai 2019. URL : http://journals.openedition.org/labyrinthe/3866 ; DOI : 10.4000/ labyrinthe.3866

Ce document a été généré automatiquement le 9 mai 2019.

Propriété intellectuelle 


\section{Le temps des revues}

